\title{
FAKTOR-FAKTOR RISIKO RISIKO DALAM PERUSAHAAN JASA PENGIRIMAN
}

\author{
Resista Vikaliana \\ Institut Ilmu Sosial dan Manajemen STIAMI \\ email : resistav31@gmail.com
}

\begin{abstract}
Abstrak. Di era globalisasi ini, tidak dapat dipungkiri bahwa jasa pengiriman barang sangat dibutuhkan, baik itu oleh individu ataupun oleh organisasi/perusahaan. Pengiriman barang (bahan baku, bahan setengah jadi, ataupun barang jadi) yang tidak tepat waktu dapat menyebabkan terhambatnya proses produksi. Jasa pengiriman paket merupakan bisnis jasa titipan barang yang sangat banyak persaingannya, oleh sebab itu pendapatan perusahaan jasa titipan barang khususnya paket cenderung fluktuatif menurun seperti yang dialami oleh salah satu jasa pengiriman dalam negeri. Dengan banyaknya persaingan bisnis jasa titipan barang, maka persaingan ke depan akan lebih meningkat atau lebih cepat berubah sehingga peta permintaan akan jasa ini juga ikut berubah, hal ini apabila perusahaan jasa titipan tidak ikut perubahan mustahil perusahaan tersebut akan eksis. ntuk itulah perlu dilakukan manajemen atas risiko yang kerapkali muncul dalam jasa pengiriman barang. langkah manajemen risiko yang bisa dilakukan di antaranya pengelolaan SDM persaingan bisnis jasa pengiriman barang, kesalahan pengiriman, kerusakan barang yang dikirim , pencurian atau kebakaran gudang. Dengan mengetahui berbagai risiko yang biasanya dihadapi oleh perusahaan, maka penanganan risiko secara cepat dan tepat dapat meminimalisir risiko yang dihadapi perusahaan, sehingga menghabiskan dana yang besar.
\end{abstract}

Kata kunci: jasa pengiriman barang, faktor-faktor risiko, perusahaan jasa pengiriman barang

Abstract. In this era of globalization, can not be denied that the delivery of goods is needed, either by individuals or by organizations / companies. Delivery of goods (raw materials, semi-finished materials, or finished goods) that are not timely can cause inhibition of the production process. Package delivery service is a business services meripan goods that are very much the competition, therefore the income of goods services companies especially package goods packages tend to fluctuate decline as experienced by one of the domestic delivery services. With so many business competition for goods merchandise services, competition in the future will increase or change faster so that the demand map of these services will also change, if the service company does not follow the change impossible the company will exist. That is why management is required for the risks that often arise in the delivery of goods. Risk management steps that can be done include the management of human resources business competition freight services, delivery errors, goods damage sent, theft or fire warehouse. By knowing the various risks typically faced by the company, then handling the risks quickly and accurately can minimize the risks faced by the company, so spend large funds.

Keywords: goods delivery services, risk factors, goods delivery company 
Resista Vikaliana, Faktor-Faktor Risiko Risiko Dalam Perusahaan Jasa Pengiriman....

\section{PENDAHULUAN}

Pada masa sekarang, tidak dapat dipungkiri bahwa jasa pengiriman barang sangat dibutuhkan, baik itu oleh individu ataupun oleh organisasi/perusahaan. Pengiriman barang (bahan baku, bahan setengah jadi, ataupun barang jadi) yang tidak tepat waktu dapat menyebabkan terhambatnya proses produksi. Inilah yang menyebabkan timbulnya kegagalan dalam usaha.

Jasa pengiriman paket merupakan bisnis jasa titipan barang yang sangat banyak persaingannya, oleh sebab itu pendapatan perusahaan jasa titipan barang khususnya paket cenderung fluktuatif menurun seperti yang dialami oleh PT. Pos. Dengan banyaknya persaingan bisnis jasa titipan barang, maka persaingan ke depan akan lebih meningkat atau lebih cepat berubah sehingga peta permintaan akan jasa ini juga ikut berubah, hal ini apabila perusahaan jasa titipan tidak ikut perubahan mustahil perusahaan tersebut akan eksis. Dalam banyak hal perubahan tersebut terutama mengetahui apa yang diinginkan oleh konsumen.

Perusahaan yang berkecimpung di industri ini banyak, antara lain Tiki JNE, Tiki, FedEx/RPX, TNT, DHL, UPS, Dermaga Samudera Biru dan lainnya. Kesemuanya kecuali TNT, bersaing langsung dengan PT Posindo dalam hal jasa pengiriman barang.

Prospek yang ada pada jasa pengiriman ini memang cerah, oleh karena itu pemainnya makin banyak dan menjamur dimana-mana. Sehingga dalam memenangkan persaingan, perusahaan harus banyak melakukan perbaikan dalam hal layanan yang diberikan. Salah satu pihak yang harus banyak berbenah nampaknya adalah PT Posindo. Keluhan dari banyak pelanggan antara lain adalah lambatnya pengiriman dan layanan seringkali mengecewakan.

Padahal faktor ini paling penting dalam jasa pengiriman. Perbedaannya, misalnya dengan FedEx, yang selalu menampilkan image speed yang on time sampai tujuan, dalam kenyataannya sebagian besar pelanggan seperti yang dilansir oleh PintuNet mengaku puas akan kecepatan FedEx. Walaupun agak lebih mahal, namun sesuai dengan pelayanan yang diberikan.

Masalah harga, PT Posindo memang paling murah dibandingkan semuanya. Tiki JNE dan JNE termasuk menengah. Sementara yang termasuk mahal adalah Fedex, DHL dan TNT. Untuk kiriman kecil seperti dokumen atau barang sampai $20 \mathrm{~kg}$ memang lebih tinggi dibandingkan dengan DHL atau TNT, tetapi kalau diatas $20 \mathrm{~kg}$ harga cenderung lebih murah dibandingkan yang lainnya. Jadi intinya, FedEx lebih sesuai untuk mengirim barang dalam container besar.

Selain persaingan, beberapa risiko yang dihadapi perusahaan jasa pengiriman, misalnya kehilangan barang ketika dalam perjalanan, barang yang rusak ketika sampai ke konsumen, kesalahan sasaran pengiriman, ataupun risiko kebakaran, dan risiko kecelakaan saat pengiriman.

dvertisements

Di dalam tulisan ini, akan dibahas beberapa risiko yang dihadapi perusahaan jasa pengiriman juga termasuk cara pemecahan dari risiko tersebut. Penulisan ini bertujuan untuk mengetahui variable - variabel apa yang menjadi issue dominan, yang dapat menjadi risiko bagi perusahaan jasa pengiriman, dalam mempengaruhi persaingan antar jasa tersebut, issue ini mengindikasikan pentingnya memahami perilaku konsumen dalam memilih jasa pengiriman paket dengan membentuk suatu model yang berkaitan dengan itu.

Selain itu, penulisan ini bertujuan untuk menemukan problem solving dari beberapa risiko yang mungkin dihadapi perusahaan jasa pengiriman. Di dalam tulisan ini pun, dibahas mengenai bagaimana membuat sebuah manajemen untuk mengatasi risiko yang dihadapi perusahaan jasa tersebut.

\section{TINJAUAN PUSTAKA}

\section{Risiko dan Manajemen Risiko}

Risiko dapat terjadi pada pelayanan, kinerja, dan reputasi dari institusi yang bersangkutan. Risiko yang terjadi dapat disebabkan oleh berbagai faktor antara lain kejadian alam, 
operasional, manusia, politik, teknologi, pegawai, keuangan, hukum, dan manajemen dari organisasi.

Risiko berhubungan dengan ketidakpastian ini terjadi oleh karena kurang atau tidak tersedianya cukup informasi tentang apa yang akan terjadi. Sesuatu yang tidak pasti (uncertain) dapat berakibat menguntungkan atau merugikan. Ketidakpastian yang menimbulkan kemungkinan menguntungkan dikenal dengan istilah peluang (Opportunity, sedangkan ketidakpastian yang menimbulkan akibat yang merugikan dikenal dengan istilah risiko (Risk).

Secara umum risiko dapat diartikan sebagai suatu keadaan yang dihadapi seseorang atau perusahaan di mana terdapat kemungkinan yang merugikan. Bagaimana jika kemungkinan yang dihadapi dapat memberikan keuntungan yang sangat besar sedangkan kalaupun rugi hanya kecil sekali?

Risiko dapat dikurangi dan bahkan dihilangkan melalui manajemen risiko. Peran dari manajemen risiko diharapkan dapat mengantisipasi lingkungan cepat berubah, mengembangkan corporate governance, mengoptimalkan penyusunan strategic management, mengamankan sumber daya dan asset yang dimiliki organisasi, dan mengurangi reactive decision making dari manajemen puncak.

\section{Kategori risiko}

Risiko dapat dikategorikan ke dalam dua bentuk:

\section{Risiko spekulatif}

Risiko spekulatif adalah suatu keadaan yang dihadapi perusahaan yang dapat memberikan keuntungan dan juga dapat memberikan kerugian.

\section{Risiko murni}

Risiko murni (pure risk) adalah sesuatu yng hanya dapat berakibat merugikan atau tidak terjadi apa-apa dan tidak mungkin menguntungkan. Salah satu contoh adalah kebakaran,

\section{Manajemen Risiko}

Manajemen risiko adalah suatu pendekatan terstruktur/metodologi dalam mengelola ketidakpastian yang berkaitan dengan ancaman; suatu rangkaian aktivitas manusia . Manajemen resiko adalah rangkaian langkahlangkah yang membantu suatu perangkat lunak untuk memahami dan mengatur ketidak pastian (Roger S. Pressman). Pada saat kita mengerjakan pengembangan perangkat lunak sering kita menghadapi berbagai situasi yang tidak nyaman seperti keterlambatan pengembangan atau pengeluaran biaya pengembangan yang melebihi anggaran. Hal ini dikarenakan kurang siapnya kita menghadapi berbagai kemungkinan resiko yang akan terjadi. Untuk itu perlu dilakukan identifikasi tindakan yang harus dilakukan untuk mencegah ataupun meminimalkan resiko tersebut.

Mengapa manajemen resiko itu penting? Sikap orang ketika menghadapi resiko berbeda-beda. Ada orang yang berusaha untuk menghindari resiko, namun ada juga yang sebaliknya sangat senang menghadapi resiko sementara yang lain mungkin tidak terpengaruh dengan adanya resiko. Pemahaman atas sikap orang terhadap resiko ini dapat membantu untuk mengerti betapa resiko itu penting untuk ditangani dengan baik.

Penilaian risiko, pengembangan strategi untuk mengelolanya dan mitigasi risiko dengan menggunakan pemberdayaan/pengelolaan sumberdaya. Strategi yang dapat diambil antara lain adalah memindahkan risiko kepada pihak lain, menghindari risiko, mengurangi efek negatif risiko, dan menampung sebagian atau semua konsekuensi risiko tertentu. Manajemen risiko tradisional terfokus pada risiko-risiko yang timbul oleh penyebab fisik atau legal (seperti bencana alam atau kebakaran, kematian, serta tuntutan hukum. Manajemen risiko keuangan, di sisi lain, terfokus pada risiko yang dapat dikelola dengan menggunakan instrumen-instrumen keuangan. 
Resista Vikaliana, Faktor-Faktor Risiko Risiko Dalam Perusahaan Jasa Pengiriman....

$\underline{\text { Sasaran }}$ dari pelaksanaan manajemen risiko adalah untuk mengurangi risiko yang berbeda-beda yang berkaitan dengan bidang yang telah dipilih pada tingkat yang dapat diterima oleh masyarakat. Hal ini dapat berupa berbagai jenis ancaman yang disebabkan oleh lingkungan, teknologi, manusia, organisasi dan politik. Di sisi lain pelaksanaan manajemen risiko melibatkan segala cara yang tersedia bagi manusia, khususnya, bagi entitas manajemen risiko (manusia, staff, dan organisasi).

Pentingnya memahami perilaku konsumen dalam memilih jasa pengiriman paket dengan membentuk suatu model yang berkaitan dengan itu. Pada studi ini pembentukan model dilakukan dengan pendekatan disaggregate melalui analisa stated preference dengan menggunakan model Logit Biner. Untuk mengidentifikasikan tingkat kepentingan dan untuk estimasi parameter model logir biner, dilakukan estimasi dengan menggunakan prosedur multiregresi linier. Dan Parameter yang diperoleh akan diperiksa dengan uji statistik. Perumusan model ditentukan oleh beberapa variabel independen yang mempunyai tingkat hubungan yang kuat, yaitu waktu tempuh paket, ketepatan datangnya kiriman paket dan keamanan paket, sehingga variabel tersebut dikombinasikan menjadi beberapa alternatip model.

Kesimpulan dari analisis mengenai model perilaku konsumen dalam memilih jasa pengiriman paket adalah pertama perlunya perubahan untuk perbaikan terhadap variabel pelayanan yang ada dalam model, karena variabel tersebut sangat berpengaruh terhadap pemilihan jasa ini, selain variabel dalam model dilakukan juga perbaikan variabel pelayanan seperti variabel biaya, kenyamanan, dan kemudahan akses ke kantor pelayanan, karena tidak menutup kemungkinan persaingan dalam bisnis ini sangat dinamis dalam rangka merebut pasar global.

Inilah beberapa contoh risiko yang
mungkin dihadapi
pengiriman, sehingga
diperlukan adanya

manajemen risiko dalam menghadapi risiko agar kerugian dapat diminimalisir.

\section{PEMBAHASAN}

\section{Telaah kasus REX}

Tak dapat dipungkiri, peran perusahaan jasa pengiriman barang saat ini begitu dibutuhkan, olehmasyarakat, baik individu maupun organisasi atau perusahaan. Jasa pengiriman barang merupakan sebuah bisnis jasa yang memberikan layanan mengirim barang titipan konsumen dari satu tempat ke tempat lain. Sebagai perusahaan jasa, maka layanan atau service terbaik merupakan kunci kesuksesannya. Walaupun kelihatannya mudah, jasa pengiriman barang juga tak lepas dari risiko yang harus dihadapi dalam pekerjaannya. Termasuk salah satu perusahaan diantaranya adalah jasa pengiriman barang REX, meskipun sudah terbilang perusahaan yang professional di bidangnya, risiko bisnis tetap harus dihadapi. Untuk itulah perlu dilakukan manajemen atas risiko yang kerapkali muncul dalam jasa pengiriman barang.Di era globalisasi ini, tidak dapat dipungkiri bahwa jasa pengiriman barang sangat dibutuhkan, baik itu oleh individu ataupun oleh organisasi/perusahaan. Pengiriman barang (bahan baku, bahan setengah jadi, ataupun barang jadi) yang tidak tepat waktu dapat menyebabkan terhambatnya proses produksi. Inilah yang menyebabkan timbulnya kegagalan dalam usaha.

Jasa pengiriman paket merupakan bisnis jasa titipan barang yang sangat banyak persaingannya, oleh sebab itu pendapatan perusahaan jasa titipan barang khususnya paket cenderung fluktuatif menurun seperti yang dialami oleh salah satu jasa pengiriman dalam negeri. Dengan banyaknya persaingan bisnis jasa titipan barang, maka persaingan ke depan akan lebih meningkat atau lebih cepat berubah sehingga peta permintaan akan jasa ini juga ikut berubah, hal ini apabila perusahaan jasa titipan tidak ikut perubahan mustahil perusahaan tersebut akan eksis. Dalam banyak hal perubahan tersebut terutama mengetahui apa yang diinginkan oleh konsumen.

\section{Telaah Kasus JNE}


Banyak risiko yang dihadapi oleh JNE sebagai perusahaan yang terjun didalam jasa pengiriman, seperti :

\section{Pengelolaan SDM}

Risiko di bidang organisasi dan SDM yaitu ddalam hal penyusunan struktur organisasi, analisa jabatan, uraian tugas, dan tanggung jawab serta recruitment, training maupun pengembangan SDM perusahaan. Dalam hal ini JNE harus menempatkan sumber daya manusianya sesuai dengan keahliannya masing-masing.

2. Persaingan antar perusahaan jasa pengiriman

Prospek yang ada pada jasa pengiriman ini memang cerah, oleh karena itu pemainnya makin banyak dan menjamur dimana-mana. Sehingga dalam memenangkan persaingan, perusahaan JNE harus banyak melakukan perbaikan dalam hal layanan yang diberikan. Jika perusahaan JNE tidak tanggap dengan persaingan yang ada maka bisa dipastikan bahwa JNE akan mengalami penurunan dalam jumlah konsum 3. Kesalahan tujuan pengiriman

Ini adalah risiko yang dialami oleh semua perusahaan jasa pengiriman, kesalahan tujuan pengiriman adalah resiko yang harus dihadapi oleh perusahaan JNE. Tujuan pengiriman yang berada dipelosok desa maupun alamat yang kurang jelas dapat menyababkan kesalahan tujuan atau sasaran dalam pengiriman barang.

4. Kerusakan pada barang yang dikirim

Kondisi jalan yang ditempuh dari asal pengiriman sampai ditujuan pengiriman tidak dapat diprediksi. Hal ini menyebabkan adanya risiko kerusakan pada barang yang dikirim. Kerusakan yang dialami saat pengiriman dapat menyebabkan konsumen kecewa dan kemudian akan memilih jasa pengiriman lain.

\section{Pencurian dan kebakaran gudang}

Banyaknya barang yang disimpan dalam gudang dan lemahnya penjagaan di areal gudang dapat menyebabkan adanya pencurian. Dan dengan adanya banyak barang yang mudah terbakar yang disimpan dalam gudang maka akan menyebabkan mudahnya terjadi kebakaran. Hal-hal ini dapat diantisipasi dengan cara mengoptimalkan security, pemasangan CCTV disetiap sudut gudang dan menghindari menyalakan api diareal gudang penyimpanan.

Maka, beberapa langkah manajemen risiko yang bisa dilakukan diantaranya :

\section{Pengelolaan SDM}

Untuk menghadapi risiko kualitas SDM dalam organisasi, biasanya dilakukan dengan cara menyusun struktur organisasi, analisis tugas dan jabatan, job description, termasuk tanggung jawab serta sistem recruitment, training hingga pengembangan SDM perusahaan secara berkelanjutan.

\section{Persaingan bisnis jasa pengiriman barang}

Prospek bisnis ini sangat cerah, sehingga makin banyak perusahaan jasa pengiriman barang yang muncul di tiap daerah. Untuk memenangkan persaingan, perusahaan jasa pengiriman barang harus melakukan perbaikan dari segi kualitas layanan yang diberikan.

\section{Kesalahan pengiriman}

Risiko yang umum dialami oleh perusahaan jasa pengiriman barang adalah kesalahan tujuan alamat pengiriman. Daerah tujuan yang berada di pelosok desa ataupun alamat tujuan yang kurang jelas bisa menyebabkan kesalahan dalam pengiriman barang.

\section{Kerusakan barang yang dikirim}

Kondisi dalam perjalanan pengiriman barang tidak dapat diprediksi. Inilah yang kerap menyebabkan risiko kerusakan barang yang dikirim. Rusaknya barang yang dialami saat pengiriman dapat menimbulkan kekecewaan pada konsumen, sehingga perlu diantisipasi dengan berbagai penanganan, misalnya : prinsip kehati-hatian dan penawaran asuransi untuk menjamin barang yang dikirim.

5. Pencurian atau kebakaran gudangBanyaknya barang titipan yang disimpan dalam gudang rawan mengundang terjadinya pencurian. Demikian pula risiko kebakaran juga mengancam barnag-barang tersebut. Langkah antisipasi yang bisa dilakukan yaitu dengan cara mengoptimalkan tenaga security, memasang CCTV di setiap sudut gudang serta hindari menyalakan api di areal gudang penyimpanan bara 
Resista Vikaliana, Faktor-Faktor Risiko Risiko Dalam Perusahaan Jasa Pengiriman....

Risiko yang dihadapi perusahaan jasa pengiriman

Persaingan antar perusahaan jasa pengiriman

b)Pencurian

c)Kesalahan sasaran pengiriman

d)Kerusakan barang

e)Kecelakaan

f)Kebakaran

2)Manajemen risiko dari perusahaan jasa pengiriman

a)Memperhatikan nilai yang diutamakan dalam perusahaan jasa pengiriman

Dalam bisnis pengiriman banyak sekali persaingan yang terjadi, karena itu dalam pelayanannya terhadap publik harus memiliki value yang diutamakan antara lain adalah :

\section{Speed atau kecepatan}

Speed adalah salah satu value yang sangat penting dalam bisnis pengiriman barang. Semakin cepat suatu barang sampai, maka value-nya semakin tinggi. Oleh karena itu umumnya suatu brand jasa pengiriman terkenal karena kecepatannya yang dapat diandalkan. Fed-Ex, misalnya yang sangat terkenal dengan ketepatan waktunya dan mereka sangat menekankan hal ini dalam layanannya.

\section{Kualitas}

Namun selain speed, kualitas juga tidak kalah penting. Tentunya Anda mengirim barang dengan harapan supaya sampai di tempat tujuan dengan utuh dan selamat, bukan? Oleh karena itu, maka kualitas disini menjadi penting. Proses yang baik dalam pelayanan akan menghasilkan kualitas yang sesuai harapan.

Tiki, misalnya menyediakan layanan pengemasan barang khusus untuk paket yang mudah retak maupun pecah.

\section{People}

Salah satu 7P dalam bisnis jasa adalah People, dan ini adalah salah satu yang terpenting dalam bisnis jasa manapun. Pelanggan mana yang ingin dilayani dengan buruk? Oleh karena itu, pelayanan pelanggan yang baik dari para karyawan juga menjadi sangat penting. Apalagi dalam bisnis pengiriman, sikap dari petugas pelayanan sangatlah penting.

\section{Promotion}

Promosi tentunya sangat penting dalam membangun awareness dan image produk kepada konsumen. Bukan hanya promosi above dan below the line saja, namun promosi dari mulut ke mulut, opini orang lain, juga berpengaruh di industri jasa ini. Oleh karena itu, kembali ke pelayanan, haruslah baik.

Pelaksanaan pelayanan dalam bisnis delivery tidak terlepas juga dari tiga unsur bauran pelayanan, yaitu people, process, dan physical evidence atau premises.

People atau sumber daya manusia (SDM) yang memberikan pelayanan harus memiliki komitmen dan ketulusan dalam memberikan pelayanan. Meskipun ini adalah profit oriented business, mereka harus nothing to lose artinya tidak mengharapkan pamrih apaapa dari pengguna pelayanan.

Untuk mencapai kualitas pelayanan publik, SDM yang andal dan dapat memberikan pelayanan yang memuaskan merupakan tuntutan yang tidak dapat dihindarkan. Perlu interaksi atau hubungan antara setiap karyawan dan departemen terkait dalam organisasi dalam memberikan pelayanan yang optimal.

Process atau gabungan semua aktivitas yang terdiri dari prosedur, mekanisme, aktivitas, dan hal-hal rutin di mana pelayanan disampaikan pada para pengguna.

Physical evidence/ Premises atau bukti fisik pelayanan publik yang terdiri dari beragam perangkat dan tempat pelayanan. Informasi dalam brosur harus akurat dan andal untuk membantu pengguna mendapatkan pelayanan yang optimal. Selain itu, tampilan fisik pelayan publik seperti keamanan barang, serta kantor pelayanan yang menunjang penyampaian pelayanan yang menarik.

\section{b)Memperhatikan hal yang dapat menjadi pertimbangan dalam proses pengiriman barang}

Beberapa hal berikut yang bisa dijadikan pertimbangan dalam proses pengiriman barang

\section{Packing}

Jenis packing manapun kekuatan packing sangat mempengaruhi apakah barang anda 
bisa selamat tiba tanpa kerusakan yang berarti.

Dalam proses packing ini perlu dilihat beberapa hal: jenis barang (pecah belah, cairan, makanan, dan sebagainya) beberapa ekspedisi tidak mau mengangkut barang pecah belah jika packing yang kita buat tidak kuat. Untuk pecah belah biasanya dilakukan packing tambahan berupa packing kayu. Tentu hal ini akan berpengaruh terhadap harga packingnya. Perlu di-ingat dalam proses pengiriman barang akan banyak dilakukan proses handling, mulai dari barang di ambil di tempat anda, di gudang ekspedisi, pada saat dimuat di kendaraan (truk) atau pada saat proses pemuatan di pesawat maupun setelah barang tiba di tujuan. Semakin banyak handling yang dilakukan maka semakin besar juga resiko kerusakan barang. Jadi jenis packing akan mempengaruhi barang tersebut rusak atau tidak lebih baik anda buat web untuk perusahaan pengiriman barang di desain web

\section{Pengiriman melalui udara}

Jika anda mengirim barang melalui udara, sebaiknya tanyakan dulu ke perusahaan pengiriman barang tersebut seberapa besar/ berat yang diperbolehkan. Karena untuk tujuan-tujuan tertentu kita tidak boleh mengirim berat barang lebih dari jumlah yang ditentukan. Misal hanya dibatasi per koli cuma $150 \mathrm{~kg}$ saja. Lebih dari $150 \mathrm{~kg}$ harus dibagi menjadi 2 koli. Hal ini dikarenakan memang aturan dari operator pesawat. Begitu juga dengan dimensi/ukuran barang.

\section{Pengiriman melalui darat}

Bisa menggunakan truk atau bis dan juga saat ini ada yang menyediakan "wagon bus" dimana bentuknya seprti bis tetapi hanya untuk angkut barang saja. Carilah perusahaan ekspedisi yang mempunyai jasa pengiriman yang sudah terjadwal setiap hari-nya. Memang cukup sulit mengetahui apakah suatu perusahaan ekspedisi itu mempunyai jadwal yang tetap atau tidak. Banyak juga perusahaan ekspedisi yang menunggu memberangkatkan barang sampai mereka mendapatkan muatan penuh baru berangkat. Jadi tidak heran jika ekspedisi a bisa kirim 2 hari untuk jkt-yogya sementara ekspedisi b bisa satu minggu.
Jika muatan sablon digital anda banyak dan harus dimuat dalam 1 truk, maka sebaiknya anda charter saja truk tersebut. Ini lebih aman karena barang tidak naik dan turun antara tempat anda, gudang ekspedisi dan tempat tujuan. Sebagai contoh perusahaan mebel di jepara hampir selalu mengirim barang mereka dalam 1 truk besar untuk dikirim ke setiap pelanggan mereka di luar kota.

\section{Pengiriman laut}

Jika muatan anda banyak (misal 20 - $25 \mathrm{~m} 3$ ) sebaiknya anda booking saja 1 container 20 feet. Atau booking 1 truk dimana nantinya truk tersebut akan naik keatas kapal. Jika barang anda sedikit memang mau tidak mau barang anda harus digabung dengan barangbarang lain.

Pengendalian Risiko dengan Asuransi

Pengalihan Risiko

Di dunia yang penuh ketidakpastian ini, salah satu cara yang dapat membantu melindungi kita dari risiko adalah Asuransi Jiwa. Asuransi adalah salah satu bentuk pengendalian risiko yang dilakukan dengan cara mengalihkan/transfer risiko dari satu pihak ke pihak lain dalam hal ini adalah perusahaan asuransi. Asuransi jiwa mengelola risiko dengan cara memindahkan dampak kerugian dari seorang individu kepada sebuah grup dan membagikan kerugian yang dialami oleh individu tersebut kepada seluruh anggota grup.

Mari kita mengingat kembali pengertian dasar seputar Asuransi yang mungkin akan membantu anda dalam merencanakan keuangan yang lebih baik lagi.

1. Pengertian asuransi

Menurut KUHD pasal 246 disebutkan bahwa "asuransi atau pertanggungan adalah suatu perjanjian dengan mana seorang penanggung mengikatkan diri kepada seorang tertanggung, dengan menerima suatu premi, untuk penggantian kepadanya karena suatu kerusakan atau kehilangan keuntungan yang diharapkan yang mungkin akan dideritanya karena suatu peristiwa yang tidak tentu".

Pengertian asuransi yang lain adalah merupakan suatu pelimpahan risiko dari pihak pertama kepada pihak lain. Dalam pelimpahan dikuasai oleh aturan-aturan hukum dan 
Resista Vikaliana, Faktor-Faktor Risiko Risiko Dalam Perusahaan Jasa Pengiriman....

berlakunya prinsip-prinsip serta ajaran yang secara universal yang dianut oleh pihak pertama maupun pihak lain.

Dari segi ekonomi, asuransi berarti suatu pengumpulan dana yang dapat dipakai untuk menutup atau memberi ganti rugi kepada orang yang mengalami kerugian.

\section{Manfaat Asuransi}

Disamping sebagai bentuk pengendalian risiko (secara finansial), asuransi juga memiliki berbagai manfaat yang diklasifikasikan ke dalam : fungsi utama, fungsi skunder dan fungsi tambahan.

Fungsi utama asuransi adalah sebagai pengalihan risiko, pengumpulan dana dan premi yang seimbang. Fungsi skunder asuransi adalah untuk merangsang pertumbuhan usaha, mencegah kerugian, pengendalian kerugian, memiliki manfaat sosial dan sebagai tabungan. Sedangkan fungsi tambahan asuransi adalah sebagai investasi dana dan invisible earnings.

3. Apakah semua risiko dapat diasuransikan?

Tidak semua risiko dapat diasuransikan. Resiko-risiko yang dapat diasuransikan adalah : risiko yang dapat diukur dengan uang, risiko homogen (risiko yang sama dan cukup banyak dijamin oleh asuransi), risiko murni (risiko ini tidak mendatangkan keuntungan), risiko partikular (risiko dari sumber individu), risiko yang terjadi secara tiba-tiba (accidental), insurable interest (tertanggung memiliki kepentingan atas obyek pertanggungan) dan risiko yang tidak bertentangan dengan hukum.

\section{Pengertian Asset}

Asset adalah segala sesuatu yang memiliki nilai jual atau nilai ekonomis. Sebuah asset dapat bersifat tangible (dpt dilihat,contohnya : mobil, rumah, tanah, seekor sapi, pabrik, dll) atau intangible (tidak dapat dilihat, contohnya : bakat dan kemampuan seseorang). Bisnis asuransi bertujuan melindungi nilai ekonomis dari asset tersebut.

Hidup manusia merupakan sebuah asset yang sangat berharga yang dapat mendatangkan pendapatan. Aset ini juga menghadapi risiko seperti kematian, sakit maupun cacat yang diakibatkan oleh kecelakaan. Risiko seperti cacat dan kematian membuat seseorang tidak mampu untuk memperoleh penghasilan. Hal ini mengakibatkan pihak-pihak yang bergantung kepadanya, misalnya keluarga, mengalami kesulitan.

5. Musibah dan Risiko

Kebanjiran, sakit, tertabrak kendaraan lain, gempa bumi, longsor, kematian dan lain-lain merupakan contoh musibah. Kerusakan atau kehancuran yang mungkin disebabkan oleh musibah-musibah tersebut adalah risiko yang dimiliki oleh asset

Pengertian 'risiko' dalam asuransi berarti adanya kemungkinan atau ketidakpastian kerugian atau kehancuran yang dihadapi oleh suatu 'asset' yang dapat menimbulkan kerugian ekonomis

Prinsip Dasar Asuransi

Dalam dunia asuransi ada beberapa prinsip dasar yang harus dipenuhi,yaitu :

1. Insurable interest

Hak untuk mengasuransikan, yang timbul dari suatu hubungan keuangan, antara tertanggung dengan yang diasuransikan dan diakui secara hukum. Sesuai dengan tujuan asuransi jiwa, setiap orang dianggap memiliki insurable interest atas dirinya sendiri, termasuk terhadap pasangan hidup dan keluarganya.

2. Utmost good faith

Dalam sebuah kontrak, umumnya setiap pihak yang terlibat dapat mempelajari produk dan subjek dari kontrak tersebut. Tetapi dalam asuransi jiwa, yang menjadi produk/subyek adalah 'hidup'seseorang. Hanya pihak tertanggunglah yang sangat memahami semua risiko yang berhubungan dengan dirinya. Merupakan tugas pihak penanggung dan pihak tertanggung untuk menerapkan niat baik (good faith) atau dalam bahasa latin disebut Uberrima Fides diantara satu sama lain. Si penanggung harus dengan jujur menerangkan dengan jelas segala sesuatu tentang luasnya syarat/kondisi dari asuransi dan si tertanggung juga harus memberikan keterangan yang jelas dan benar atas obyek atau kepentingan yang dipertanggungkan.

3. Proximate cause adalah suatu penyebab aktif, efisien yang menimbulkan rantaian kejadian yang menimbulkan suatu akibat tanpa adanya intervensi suatu yang mulai dan secara aktif dari sumber yang baru dan independen.

4. Indemnity

Suatu mekanisme dimana penanggung menyediakan kompensasi finansial dalam 
upayanya menempatkan tertanggung dalam posisi keuangan yang ia miliki sesaat sebelum terjadinya kerugian (KUHD pasal 252, 253 dan dipertegas dalam pasal 278).

5. Conditional (bersyarat)

Kontrak asuransi jiwa memiliki persyaratan. Pihak penanggung terikat janji untuk membayar kompensasi apabila persyaratanpersyaratan tertentu telah terpenuhi.

6. Unilateral

Kontrak asuransi jiwa pada dasarnya bersifat sepihak. Hanya satu pihak saja, pihak penanggung yang mempunyai janji legal yang harus dilaksanakan. Pihak tertanggung tidak dapat dipaksa secara legal untuk membayar premi.

\section{Aleatory}

Jika pihak tertanggung meninggal dunia setelah membayar satu kali premi, ahli waris akan mendapatkan ganti rugi penuh (yang jumlahnya mungkin jauh lebih besar daripada satu kali premi) Sebaliknya, perusahaan risiko perusahaan. Dengan asuransi, kerugian perusahaan dapat diminimalisir. Asuransi yang biasanya digunakan oleh perusahaan

\section{SIMPULAN}

Dari pembahasan di atas, dapat disimpulkan bahwa :

1. Mengetahui berbagai risiko yang biasanya dihadapi oleh perusahaan adalah mutlak dilakukan. Hal ini disebabkan karena penanganan risiko secara cepat dan tepat dapat meminimalisir risiko yang dihadapi perusahaan.

2. Beberapa manajemen risiko yang akan diterapkan oleh perusahaan haruslah manajemen yang paling aman dan mudah dilakukan, juga tidak terlalu menghabiskan dana yang besar. asuransi jiwa dapat memperoleh uang yang lebih besar dari hasil premi ketimbang uang ganti rugi yang harus dibayarkan.

8. Personal

Kontrak asuransi jiwa bersifat pribadi. Seseorang pasti mungkin insurable interest di dirinya sendiri, tetapi orang lain mungkin tidak memiliki insurable interest pada orang tersebut. Jadi, kontrak asuransi jiwa tidak dapat dipindahkan kepada orang lain.

9. Valued

Dibawah kontrak asuransi jiwa, penanggung setuju untuk membayar sejumlah kompensasi saat kerugian timbul. Jumlah yang dibayarkan kepada ahli waris tersebut mungkin atau mungkin tidak memiliki hubungan dengan jumlah kuantitatif dari kerugian yang timbul akibat kematian tertanggung.

Begitu pula dengan perusahaan jasa pengiriman, bahwa sebenarnya asuransi sangat dibutuhkan di dalam menghadapi jasa pengiriman adalah asuransi jasa pengiriman.

\section{DAFTAR PUSTAKA}

Siahaan, Hinsa. 2009.Manajemen Risiko pada Perusahaan dan Birokrasi. Elex Media Komputindo, Jakarta.

Pramana, Tony. 2011. Manajemen Risiko Bisnis. Sinar Ilmu Publishing, Jakarta

Sumber Internet:

http://kangandri.blogspot.co.id/2011/08/aplikasimanajemen-risiko-dalam.html https://pengirimanbrg.wordpress.com/2015/02 /06/manajemen-risiko-pada-perusahaan-jasapengiriman-barang/

http://gusasta.blogspot.co.id/2013/12/identifik asi-risiko-risiko-yang-mungkin.html 